\title{
Toxigenic Potential of Vibrio cholerae O1and 0139 Serotypes Isolated from Cases of Diarrhea in Baghdad hospitals

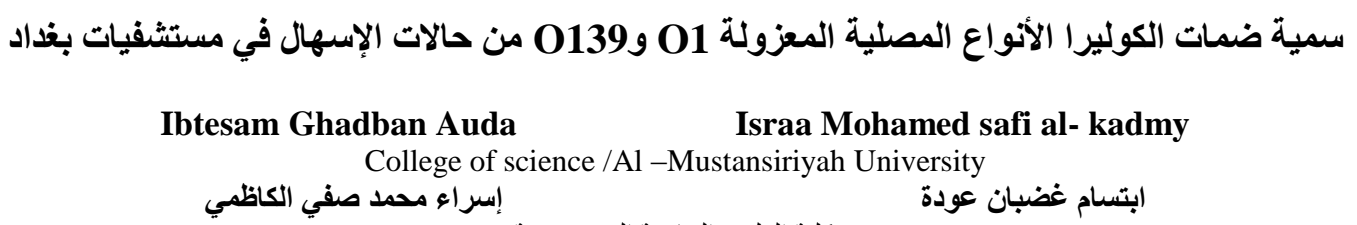

Abstract

Cholera is most important water borne pathogen. The public health significance of a $\mathrm{V}$. cholerae isolate is routinely assessed by two critical properties: the production of cholera toxin CT and the possession of either the 01 or 0139 antigen, which acts as a marker of epidemic potential. The objective of this study is to detect $V$. cholerae serotypes directly from stools and determines their toxiginicity potential. Sixty four stool samples were collected from four hospitals in Baghdad from November 2010 to February 2011. The age of patients was ranging from two months to 12 years, 26 females and 38 males. Immunochromatographic test used for qualitative detection of O1and /or 0139 serotypes was used in addition to routine culture for isolation of $V$. cholerae. Using specific primer cholera toxin gene, $\operatorname{ctxA2-B}$, was amplified and the PCR product was detected by agarose gel electrophoresis. Out of 64 stool samples only $16(25 \%)$ was positive. Fifeen $93.7 \%$ of these samples were positive for O1serogroup and just one $6.3 \%$ was positive for 0139 serogroup. Stool sample culture on alkaline peptone water and then on TCBS agar enhance the growth of $11(17.2 \%) V$. cholerae isolates, $10(90.9 \%)$ were belong to 01 serotype and one $9.1 \%$ belong to 0139. The results of $\operatorname{ctxA2-B}$ gene amplification show that, $9(90 \%)$ out of 10 O1serotypes was positive. While the only one $100 \% 0139$ serotype was positive. As conclusion, the incidence of cholera caused by $V$. cholerae 01 is more than that caused by $V$. cholerae 0139 in Baghdad hospitals. Immunochromatographic test is a rapid and sensitive test in recover $V$. cholerae 01 and 0139 serotypes. PCR is a simple molecular tool to determine the toxigenicity of $V$. cholerae isolates.

Key words: Vibrio cholera, 01 or 0139 antigen

$$
\begin{aligned}
& \text { تعتبر الكوليرا من الامر اض المهمة وان اهميتها في مجال الصحة العامة تاتي من صفتين الاولى افراز ذيفان الكوليرا وامتلاك احد }
\end{aligned}
$$

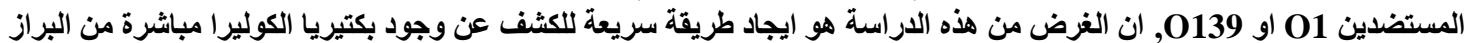

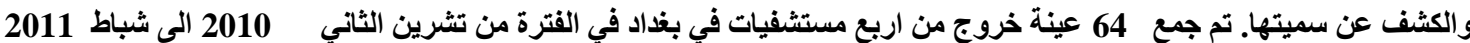

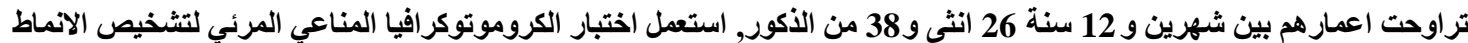

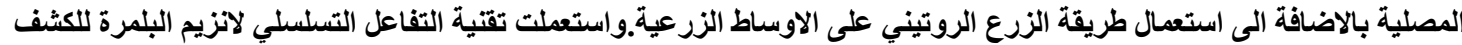

$$
\begin{aligned}
& \text { عن وجود جين ذيفان الكوليرا, 16(25\%) من عينات الخروج اعطت نتيجة موجبة كانت منها 15 (93.7\% }
\end{aligned}
$$

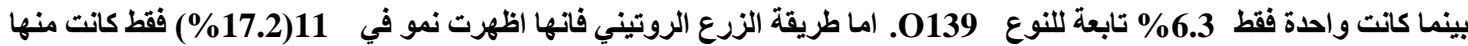

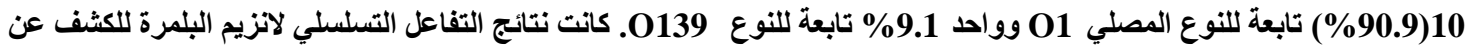

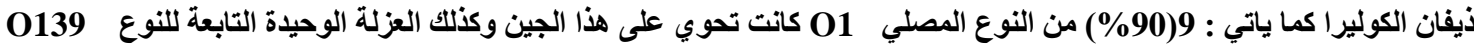

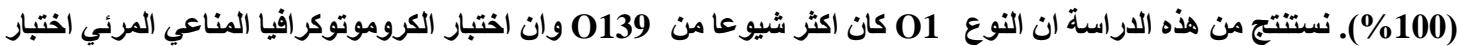

$$
\begin{aligned}
& \text { حساس للكثف عن بكتيريا الكوليرا وان اختبار التفاعل التسلسلي لانزيم البلمرة هو وسيلة جزيئية سهلة في الكثف عن عن قابلية } \\
& \text { البكتيريا على انتاج الأيفان . }
\end{aligned}
$$

\section{Introduction}

Vibrio cholerae is a facultative anaerobic, Gram negative, non-spore forming curved rod. It is a human pathogen found in coastal waters that causes the acute gastrointestinal disease. Cholera is a major health threat in poor nations. It is widely acknowledged as one of the most important water borne pathogen[1]. The threat of epidemic cholera is restricted primarily to developing countries with warm climates [2]. There are 139 different $\mathrm{O}$ groups. $V$. cholerae $\mathrm{O} 1$ and $\mathrm{O} 139$ are known to be the dominating and pathogenic strains [1]. The public health significance of a $V$. cholerae isolate is routinely assessed by two critical properties: the production of cholera toxin (CT) and the possession of either the $\mathrm{O} 1$ or 0139 antigen, which acts as a marker of epidemic potential. So far, agents of endemic and pandemic cholera 
have been represented exclusively by CT-producing V. cholerae strains. Cholera toxin has been shown to be the key virulence factor responsible for the manifestation of massive, dehydrating diarrhea [2,3,4]. The pathogenicity of Vibrio cholerae is chiefly associated with the secretion of the CT, which is a protein complex.

The structure of CT is typical subunit group of toxins in which each of the subunits has a specific function [1]. The A subunit functions for adenylate cyclase activation in small intestinal epithelial cells, leading to the loss of fluid and electrolytes. The binding (B) subunits of $11500 \mathrm{Da}$ each serves to bind the toxin to the epithelial cell surface receptor [5]. The catalytic A subunit must gain access to the cell cytosol for CT to exert its toxic effects [6]. The genes expressing A and B subunits are designated $\operatorname{ctxA}$ and $c t x B$, respectively, and are expressed as a single transcriptional unit [5].

Detection of CT-producing V. cholerae using conventional culture-, biochemical- and immunologicalbased assays is time-consuming and laborious, requiring more than three days. A rapid, reliable and practical assay for the detection of CT-producing V. cholerae has thus been sought. Several PCR assays offer a more sophisticated approach to the identification of $V$. cholerae [7].

Although PCR assays provide more rapid identification of $V$. cholerae than conventional assays, they require the use of electrophoresis to detect amplified products, which is time-consuming and tedious. Real time PCR assays recently developed for the rapid identification of $V$. cholerae [8]. Real time PCR assays are not routinely used due to their requirement for an expensive thermal cycler with a fluorescence detector $[9,10]$. PCR has now become a frequently used detection method, and several PCR protocols have been developed for $V$. cholerae $[11,12,13]$.

In this study we investigate the incidence of $V$. cholerae $\mathrm{O} 1$ and $\mathrm{O} 139$ serotypes for diarrheal cases in Baghdad city and their toxigenic potential.

\section{Materials and methods}

Sixty-four stool samples were collected from four hospitals, Al-Kadhymia teaching hospital, AlKadhymia hospital for children, Children protection hospital in Al-Mansur neighbourhood and Baghdad teaching hospital. The age of patients was ranging from two months to 12 years, 26 females and 38 males.

Immunochromatographic one step visual test for $V$. cholerae (Crystal VC-India), for qualitative detection of O1and /or O139 serogroups was used. This test based on the principle of immunochromatographic, in which the nitrocellulose membrane is coated with monoclonal antibodies to V. cholerae O1and O139 LPS as two separated bands.

Alkaline peptone water was prepared as an enrichment broth, as follows $10 \mathrm{~g}$ of peptone and $10 \mathrm{~g}$ of sodium chloride were dissolved in $800 \mathrm{ml}$ of distilled water, the $\mathrm{pH}$ was adjusted to 8.5 then the volume was completed to $1000 \mathrm{ml}$ then autoclaved. Thiosulfate citrate bile salts sucrose (TCBS) agar is the selective agar medium of choice for isolating $V$. cholerae. Ten milliliters of alkaline peptone water were inoculated with about $1 \mathrm{ml}$ of stool sample that was positive when tested by Immunochromatographic one step visual test and then incubated $6 \mathrm{hrs}$ at $35-37^{\circ} \mathrm{C}$. After $6 \mathrm{hrs}$ of incubation, about $0.1 \mathrm{ml}$ was inoculated on the surface of TCBS Agar [14].

The total DNA of $V$. cholerae O1and 0139 serotypes were extracted by simple and rapid boiling procedure. Briefly, portions of individual bacterial colonies were suspended in $200 \mu \mathrm{l}$ of lysis buffer containing $1 \%$ Triton $\mathrm{X}-100,0.5 \%$ Tween $20,10 \mathrm{mM}$ Tris- $\mathrm{HCl}(\mathrm{pH}=8.0)$, and $1 \mathrm{mM}$ EDTA and incubated for 3 minutes in a boiling water bath. After centrifugation for 2 minutes at 10,000 $\times g$ to sediment the debris, a 10- $\mu$ l aliquot of the clear supernatant was directly used for agarose gel electrophoresis [15] and 5- $\mu$ l aliquot transferred to the PCR Master mix of PCR [16].

The sequence of oligonucleotide primers that were used in PCR to detect the presence of $c t x A 2-B$ gene were taken from [17] and synthesized in Alpha DNA Co. (Canada). Table (1) showed primers sequence and their PCR product. This gene was amplified using PCR, 5- $\mu$ l aliquot of the DNA supernatant was directly transferred to the PCR Master mix as a template. The amplification was performed as follows (according to the manufacturer instruction- Promega-USA):

$\begin{array}{lr}\text { Go-Taq green master mix } & 12.5 \mu \mathrm{l} \\ \text { Each primer (set of } 10 \text { picomol } \backslash \mu \mathrm{l} \text { each) } & 1.5 \mu \mathrm{l} \\ \text { Nuclease free distilled water } & 4.5 \mu \mathrm{l} \\ \text { DNA template } & 5 \mu \mathrm{l}\end{array}$

DNA template 
The PCR reaction was performed with a denaturing step at $94{ }^{\circ} \mathrm{C}$ for 5 minutes, followed by 30 cycles at $94{ }^{\circ} \mathrm{C}$ for 45 seconds, $52{ }^{\circ} \mathrm{C}$ for 50 seconds, and $72{ }^{\circ} \mathrm{C}$ for one minute. Sterile distilled water was used instead of DNA template to ensure absence of contaminants in the reaction preparations [17].

Table (1): The sequence of $c t x A 2-B$ gene specific primer set and its product size

\begin{tabular}{cccc}
\hline primer & Sequence $\left(5^{\prime} \mathbf{3}^{\prime}\right) \rightarrow$ & gene & PCR product \\
\hline C2F & AGGTGTAAAATTCCTTGACGA & ctxA2-B & 385bp \\
C2R & TCCTCAGGGTATCCTTCATC & & \\
\hline
\end{tabular}

\section{Results}

Immunochromatographic one step visual test figure (1) shows that, out of 64 stool samples only 16 (25\%) was positive. Fifeen $93.7 \%$ of these samples were positive for O1serogroup and just one $6.3 \%$ was positive for O139 serogroup. Stool sample culture on alkaline peptone water and then on TCBS agar enhance the growth of $11(17.2 \%) \mathrm{V}$. cholerae isolates, 10 (90.9\%) were belong to O1 serotype and one $9.1 \%$ belong to 0139 Table $(2,3)$.

Table (2): Number and percentage of positive and negative $V$. cholerae 01 and 0139 serotypes using two methods.

\begin{tabular}{|c|c|c|c|c|}
\hline \multirow{3}{*}{$\begin{array}{l}\text { No of stool } \\
\text { samples }\end{array}$} & \multicolumn{2}{|c|}{ Immunochromatographic test } & \multicolumn{2}{|c|}{ Culture } \\
\hline & \multirow[t]{2}{*}{ Negative } & \multirow{2}{*}{$\begin{array}{l}\text { Positive } \\
\text { O1 }\end{array}$} & \multirow[t]{2}{*}{ Negative } & Positive \\
\hline & & & & 0139 \\
\hline \multicolumn{5}{|c|}{0139} \\
\hline \multirow[t]{2}{*}{64} & 48 & 15 & 53 & 10 \\
\hline & $(75 \%)$ & $(25 \%)$ & $(82.8 \%)$ & $(17.2 \%)$ \\
\hline
\end{tabular}

Table (3): Number and percentage of positive $V$. cholerae $\mathrm{O1}$ and 0139 serotypes using two methods.

\begin{tabular}{ccccc}
\hline $\begin{array}{c}\text { V. cholerae } \\
\text { serotypes }\end{array}$ & $\begin{array}{c}\text { Positive stool } \\
\text { culture }\end{array}$ & Percentage (\%) & $\begin{array}{c}\text { Positive } \\
\text { Immunochromatographic test }\end{array}$ & Percentage (\%) \\
\hline O1 & 10 & 90.9 & 15 & 93.7 \\
O139 & 1 & 9.1 & 1 & 6.3 \\
Total & 11 & 100 & 16 & 100 \\
\hline
\end{tabular}

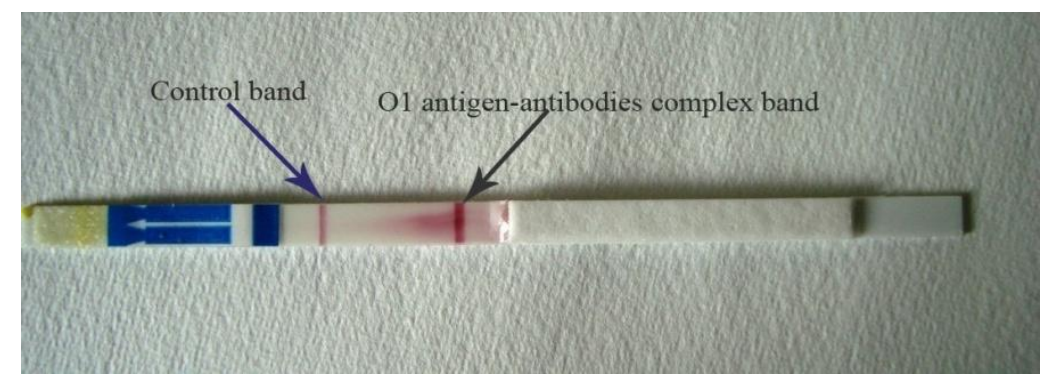

Fig.( 1): Vibrio cholerae 01 positive result by immunochromatographic one-step visual test. Two bands of 01 antigen -antibodies complex and control are appear.

The results of $c t x A 2-B$ gene amplification showed that, $9(90 \%)$ out of 10 O1serotypes was positive and only one (10\%) was negative. While the only one $100 \%$ O139 serotype was positive Table (4), figure (2).

Table (4): results of $\operatorname{ctxA2-B}$ gene amplification

\begin{tabular}{cccc}
\hline Results & O1 & O139 & Total \\
\hline Positive (\%) & $9(90 \%)$ & $1(100 \%)$ & $10(90.9 \%)$ \\
Negative (\%) & $1(10 \%)$ & $0(0 \%)$ & $1(9.1 \%)$ \\
Total & $10(100 \%)$ & $1(100 \%)$ & $11(100 \%)$ \\
\hline
\end{tabular}

\section{Discussion}

The present study investigate the incidence of $V$. cholerae serotypes in diarrheal cases of children, 25\% of the cases was due to $V$. cholerae $\mathrm{O} 1$ and O139. It was high percentage as there are many diarrhea 
causative agents in children [18].

All of serotypes obtained were belonging $V$. cholerae O1 in the outbreak in Iraq in 2007-2009[19]. In this study, O139 serotype was found in outbreak of 2011.

Vibrio cholerae serotype $\mathrm{O} 1$ had been considered the only causative agent of epidemic cholera until the emergence of $V$. cholerae serotype O139 in Bengal in 1992 in southern India [20] .The first incidence of O139 was recorded in Baghdad, Iraq, in 1999 [21]. This study is the second incidence of O139 serotype. $V$. cholerae $\mathrm{O} 139$ can disseminate widely, causing severe watery diarrhea that is clinically indistinguishable from that caused by $V$. cholerae $\mathrm{O} 1$ strains.[20]

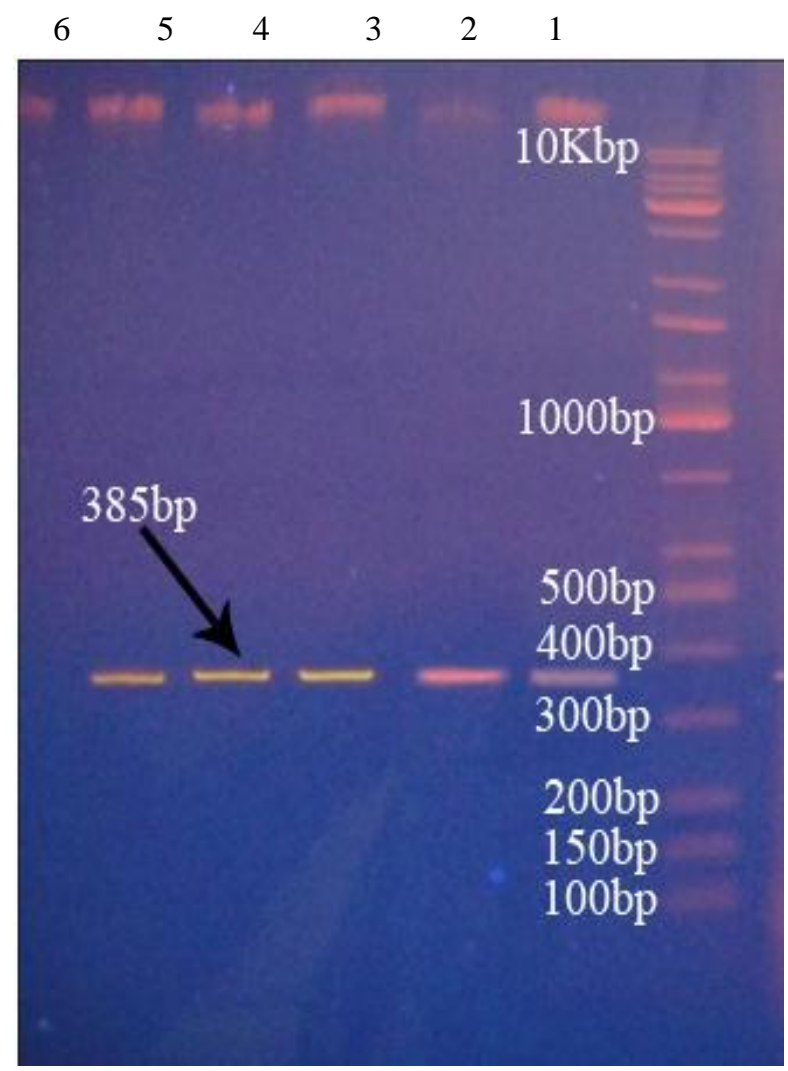

Fig. (2): Agarose gel electrophoresis of $\operatorname{ctxA2-B}$ gene PCR products. Lane 1:100bp ladder, lanes 2-6 represent ctxA2-B PCR products of Vibrio cholera $(385 \mathrm{bp})$. Electrophoresis was carried out in $1.5 \%$ agarose gel supplied with Ethidium bromide at $(7 \mathrm{~V} / \mathrm{cm})$ for 90 minutes.

In our study $90 \%$ of O1 serotype was positive to $\operatorname{ctx} A 2-B$ gene this result is relatively similar to that of [6] who found that $91.7 \%$ of O1 serotype was positive ,while $l$ [10], and [22] found that $100 \%$ of O1 serotype was positive to this gene.

For the toxigenic strains of $V$. cholerae, there is a prophage known as CTX $\Phi$ integrated in the chromosome; this genetic element comprises a $4.5-\mathrm{kb}$ central core region that contains $\operatorname{ctxAB}$ gene as well as, zot, ace, orf $U$, and cep genes, flanked by one or more copies of the repetitive sequence [23]. ctxAB gene can occur in multi copies in O139 serotype, since [24] found that, 68.8\% of O139 serotype had two copies of $\operatorname{ctxAB}, 23.9 \%$ had one copy and $7.3 \%$ had three copies or more. The high bacterial toxigenic potential may be attributed to the high copy number of cholera toxin gene.

The rapid test, like Immunochromatographic one step visual test, in combination with effective health management would result in lower incidence of mortalities during the culture period. On the other hand rapid molecular methods, like PCR, can be used as a rapid method for detection of pathogenic Vibrio spp [13] and can give an idea about their toxigenic potential and their ability to cause severe disease [17].

We conclude that, $V$. cholerae $\mathrm{O} 1$ is more predominant than $V$. cholerae $\mathrm{O} 139$ among $V$. cholerae strains isolated from cases of cholera in Baghdad. Immunochromatographic test is a rapid and sensitive method in recover $V$. cholerae serotypes. Cholera toxin gene, $\operatorname{ctxA2-B}$, is a common gene among both $V$. 
cholerae $\mathrm{O} 1$ and $\mathrm{O} 139$ serotypes in the isolates of this study. PCR is a simple molecular tool to determine the toxigenicity of $V$. cholerae isolates.

\section{References}

1. Maheshwari, M., Nelapati, K. and Kiranmayi, B. (2011). Vibrio cholerae - A Review. Vet. World. 4(9):423-428.

2. Faruque, S.M. and Nair, G.B. (2006). Epidemiology. In The biology of Vibrios Edited by: Thompson FL, Austin B, Swings J. ASM press. 385-398.

3. Ang, G.Y., Yu, C.Y., Balqis, K., Elina, H.T., Azura, H., Hani, M. H. and Yean, C.Y. (2010). Molecular Evidence of Cholera Outbreak Caused by a Toxigenic Vibrio cholerae O1 El Tor Variant Strain in Kelantan, Malaysia. J Clin Microbiol. 48(11): 3963-3969.

4. Nishibuchi, M, and DePaola, A. (2005). Vibrio species. In Foodborne pathogens: Microbiology and molecular biology Edited by: Fratamico PM, Bhunia AK, Smith JL. Horizon Scientific Press. 251-27.

5. Mekalanos, J.J., Swartz, J.D. and Pearson, G.D.N. (1983).Cholera toxin gene: nucleotide sequence, deletion, analysis and vaccine development. Nature . 306: 551- 557.

6. Mohapatra, S.S. Ramachandran, D., Mantri, C.K. and Singh, D.V. (2007). Characterization of the genetic background of Vibrio cholerae O1 biotype El Tor serotype Inaba strains isolated in Trivandrum, southern India. J Med Microbiol. 56: 260-265.

7. Hoshino, K., Yamasaki, S., Mukhopadhyay, AK., Chakraborty, S., Basu, A., Bhattacharya, SK., Nair, GB., Shimada, T., Takeda, Y. (1998). Development and evaluation of a multiplex PCR assay for rapid detection of toxigenic Vibrio cholerae O1 and O139. FEMS Immunol Med Microbiol. 20:201-207.

8. Blackstone, GM., Nordstrom, JL., Bowen, MD., Meyer, RF., Imbro, P., DePaola, A. (2007). Use of a real time PCR assay for detection of the ctxA gene of Vibrio cholerae in an environmental survey of Mobile Bay. J Microbiol Methods.68:254-259.

9. Yamazaki, W., Seto, K., Taguchi, M., Ishibashi, M. and Inoue, K. (2008). Sensitive and rapid detection of cholera toxin-producing Vibrio cholerae using a loop-mediated isothermal amplification. BMC Microbiol. 8:94

10. Fykse, E.M., Skogan, G., Davies, W., Olsen, J.S and Blatny, J.M. (2007). Detection of Vibrio cholerae by Real-Time Nucleic Acid Sequence-Based Amplification. Appl Environ Microbiol. 73(5): 1457-1466.

11. Gubala, A.J. (2006). Multiplex real-time PCR detection of Vibrio cholerae. J Microbiol. Methods. 65:278-293.

12. Gubala, A.J., and D.F. Proll. (2006). Molecular-beacon multiplex real-time PCR assay for detection of Vibrio cholerae. Appl. Environ. Microbiol. 72: 6424-6428.

13. Caipang, C. M. A. and Aguana, M.P.N. (2011). Conventional PCR assays for the detection of pathogenic Vibrio spp. in shrimp aquaculture in the Philippines. AACL Bioflux. 4 ( 3): 339-350.

14. Shahcheraghi, F. Rahbar, M. Zahraei, S.M. Nikbin, V.S. and Shooraj, F. (2009). Transmission of Vibrio cholerae O1 serotype Inaba in a rural area of Qazvin, Iran associated with drinking water. Asian J Epidemiol. 2(3): 66-71.

15. Sambrook, J. and Russell, D. (2011). Molecular Cloning: Laboratory Manual. $3^{\text {rd }}$ ed. Cold Spring Harbor, New York.USA.

16. Reischl, U., Linde, H., Metz, M., Leppmeier, B. and Lehn, N. (2000). Rapid identification of methicillin-resistant Staphylococcus aureus and simultaneous species confirmation using realtime fluorescence PCR. Clin Microbiol. 38(6): 2429-35.

17. Wei, S., Chern, L., Wu, Y., Wang, Y., Lin, C., Chiou, C. (2008). Foodborne disease outbreaks caused by sucrose-nonfermenting and $\beta$-galactosidase-deficient variants of Vibrio cholera. Intern J Food Microbiol. 122: 148-155.

18. Forbes, B.A., Sahm, D.F. and Weissfeld, A.S. (1998). Bially and Scott's Diagnostic Microbiology. 10th ed. Mosby. USA.

19. Saleh, T.H., Sabbah, M.A., Jasem, K.A. and Hammad, Z.N. (2011). Identification of virulence factors in Vibrio cholerae isolated from Iraq during the 2007-2009 outbreak. Can J Microbiol. 57:(12) 1024-1031.

20. Cholera Working Group, International Center for Diarrhoeal Disease Research, Bangladesh. (1993). Large epidemic of cholera like disease in Bangladesh caused by Vibrio cholerae O139 synonym Bengal. Lancet .342:387-390.

21. Al-Abbassi, AM., Ahmed, S., Al-Hadithi, T. (2005). Cholera epidemic in Baghdad during 1999: clinical and bacteriological profile of hospitalized cases. East Mediterr Health J.11:6-13. 
22. Nishibori, T. de Vries, G. C., Rahardjo, D. et al. (2011). Phenotypic and genotypic characterization of Vibrio cholerae clinical isolated in Surabaya, Indonesia. Jpn J Infect. Dis. 64: 7- 12

23. Basu, A., A. K. Mukhopadhyay, C. Sharma, J. Jyot, N. Gupta, A. Ghosh, S. K. Bhattacharya, Y. Takeda, A. S. G. Farque, M. J. Albert, and G. B. Nair. (1998). Heterogeneity in the organization of the CTX genetic element in strains of Vibrio cholerae O139 Bengal isolated from Calcutta, India and Dhaka, Bangladesh and its possible link to the dissimilar incidence of O139 cholera in the two locales. Microb Pathog. 24:175-183.

24. Qu, M. Xu, J. Ding,Y. Wang, R. Liu, P. Kan, B. Qi, G. Liu, Y. and Gao, S. (2003). Molecular Epidemiology of Vibrio cholerae O139 in China: Polymorphism of Ribotypes and CTX Elements. J Clin Microbiol. 41(6)2306-2310. 